DOI: 10.17707/AgricultForest.61.4.03

\author{
Ljubiša KOLARIĆ, Vera M. POPOVIĆ, \\ Jelena PAUNOVIĆ, Ljubiša ŽIVANOVIĆ, \\ Jela IKANOVIĆ, Vladimir SIKORA ${ }^{1}$
}

\title{
SUGAR BEET YIELD AND QUALITY IN THE AGROECOLOGICAL CONDITIONS OF CENTRAL BANAT, SERBIA
}

\begin{abstract}
SUMMARY
Sugar beet (Beta vulgaris L.) is one of the most important plants intended for the domestic industry in Serbia. The main objective of this work was to study the effect of cultivar and the harvest date on the yield and quality of sugar beet (sugar content). During two-year period (2013 and 2014), the influence of different harvest dates (25.8-1.9. and 28.10-10.11) on sugar beet yield and quality of selected genotypes was conducted. Research was carried out by field micro experiments in agroecological conditions of Central Banat (Zlatica, Zrenjanin), on chernozem soil type. Experiments were conducted by total random block system method in five replications.

The obtained results show that higher root yield was given by the latersecond harvest date, and sugar content by the earlier-first harvest date. Statistical differences were at very high level. The highest root yield was given by $\mathrm{cv}$. Alfonsa and the sugar content by cv. Jasmina EPD.
\end{abstract}

Keywords: root yield, sugar content, cultivar, harvest date, sugar beet

\section{INTRODUCTION}

Sugar beet (Beta vulgaris L.) is one of the most important plants intended for the domestic industry. In Serbia sugar beet starts to cultivate at the end of the XIX and beginning of XX century. After many years, the area under this crop drastically reduced and in recent times they are increased and now amount to 50 to 65,000 hectares. Root consists in average of $75-80 \%$ water and $20-25 \%$ of dry matter. The largest part of dry matter belongs to soluble sugars $16-19 \%$. On second place is cellulose with $4-5 \%$ and after them are mineral salts $1.5 \%$, nitrogen matters $1,5 \%$ and oils $0,2 \%$ (Bojovic et al, 2014). The main reason lies in the fact that it is considered profitable industrial plant, as indicated by market prices.

Genus Beta, is a member of the family Chenopodiaceae, which in the cultivated group comprises sugar beets (Beta vulgaris saccharifera), fodder beets (Beta vulgaris crassa), leaf beets (Beta vulgaris cicla) and garden beets (Beta

\footnotetext{
1 Ljubiša Kolarić, (corresponding authors: kolaric@agrif.bg.ac.rs; bravera@eunet.rs), Jelena Paunović; Ljubiša Živanović, Jela Ikanović, University of Belgrade, Faculty of Agriculture, Nemanjina 6, Zemun, SERBIA, Vera Popović, Vladimir Sikora, Institute of Field and Vegetable Crops, Maksima Gorkog 30, Novi Sad, SERBIA;

Note: The authors declare that they have no conflicts of interest. Authorship Form signed online.
} 
vulgaris rubra) (Ninfale and Angelino, 2013, Trifunovic et al. 2015). The issue of determining the optimal deadline for the extraction of the variety of different types of technology has been the subject of study for many domestic and foreign researchers (Jozefyova, L., 2003; Heidari, G. et al, 2008; Filipovic et al., 2009, Kolaric et al., 2015). Soil characteristics influence nutrient solubility, but also microbial activity and root growth (Knežević et al. 2014).

Weather removing a large extent determines how the yield and the quality or content of sugar in the root. The results of many studies almost unequivocally indicate that sugar beet mined in subsequent periods higher productivity (Jozeryova, L., 2003; Heidari, G. et al, 2008; Filipovic et al., 2009; Hussein, M., et al 2012; Mahdi, N. et al 2013). Also, in recent times, the selection of the house engaged in the production of seed of hybrid varieties of sugar beet, in order to improve and increase the productivity of their material-varieties, developed modern technologies that have shown a lot of justification. New technological solutions are known for example: Called EPD (Early Plant Development or fast initial growth) selection house KWS or StartUp technology selection house SESVANDERHAVE. They are characterized by the application of special technologies of seed for each game. These procedures seeds are practically "be activated", has a faster initial growth, balanced germination, faster assembly lines which eventually results in higher productivity.

The main objective of this work was to study the effect of cultivar and the harvest date on the yield and quality of sugar beet (sugar content). Based on these results and their analysis would be made choice KWS varieties of sugar beet of best quality in the agroecological conditions of Central Banat, on chernozem soil type.

The importance of this research consists in the fact that the obtained results will serve as a theoretical contribution to improving the technological process for the optimal use of yield potential of varieties in sugar beet production. So, the basic idea is that in the concrete conditions of climate and soil proper selection of varieties and of harvesting can increase utilization of habitats and genotype.

\section{MATERIAL AND METHODS}

The influence of the cultivar and the harvest date of sugar beet yield and quality was carried out during 2013 and 2014 on the experimental field of agricultural advisory services in Zrenjanin (Zlatica locality) in Serbia. Experiments have been conducted on chernozem soli type with following chemical characteristics: $\mathrm{pH}$ in $\mathrm{H}_{2} \mathrm{O}-8.29 \mathrm{pH} \mathrm{KCl}-7.57$, humus - $3.52 \% \mathrm{CaCO}_{3}$ - 5.64\% $\mathrm{P}_{2} \mathrm{O}_{5}-15.98 \mathrm{mg} / 100 \mathrm{~g}$ land and $\mathrm{K}_{2} \mathrm{O}-26.83 \mathrm{mg} / 100 \mathrm{~g}$ soil. Field microexperiments were conducted by total random block system method in five replications. Plot area for root yield was $10.0 \mathrm{~m}^{2}$. The study included two factors:

\section{Cultivar (A)}

A1 - Alfonsoa, A2 - Marianka, A3 - Terranova, A4 - Odessa, A5 Jasmina EPD; A6 - Bruna EPD, A7 - Marinella EPD, A8 - Serenada EPD. 
2. Harvest date $(\mathrm{B})$

$\mathrm{B}_{1}-\mathrm{I}^{\text {st }}(25.08-01.09)$

$\mathrm{B}_{2}-\mathrm{II}^{\text {nd }}(25.10-10.11)$

Applied growing technology was standard, as well as for the regular production of sugar beet. In both years preceding crop was winter wheat. After the wheat harvest was done plowing of stubble at a depth of $10-15 \mathrm{~cm}$. The main tillage is performed during the autumn, at a depth of about $30 \mathrm{~cm}$. During the spring was performed additional tillage and seedbed preparation. Basic fertilization was done mineral fertilizers NPK formulation 8:16:24 in the amount of $460 \mathrm{~kg}$ ha-1 (2013), or with NPK 7:20:30 in the amount of $356 \mathrm{~kg}$ ha-1 (2014), and additional urea in a quantity of $116 \mathrm{~kg}$ ha-1 (2013) and $145 \mathrm{~kg}$ ha-1 (2014). During growing season of sugar beet in both years, applied and foliar nutrition Wuxal Boroni in an amount of $2 \mathrm{l}$ ha-1. Weed control was done herbicides on three occasions (I treatment: Betanal AM New Safari +++ Goltix Trend; II treatment: Betanal Expert + Goltix Safari +++ Focus ultra Lontrel; III treatment Betanal MaxxPro + Lontrel + Goltix). Controlling harmful insects obaljeno the preparation FASTAC two treatments against agents of leaf spot disease (Cercospora beticola), also in the two treatments were used fungicides Sphera and ultra Duett.

Sowing plot investigation was carried out manually, according to the plan of sowing, 17.04.2013 year and 21.03.2014, and the extraction of roots in two terms, namely: (first term 01.09.2013, and II deadline 28.10.2013, ie first term 25.08. - 01.09.2014, and II deadline 20.10. - 10.11.2014 year). Removing the root was done by hand in one day, and root yield was found with 2 internal order weighing all of the tail with an area of $10.0 \mathrm{~m}^{2}$. Samples for chemical analysis of root were taken from each plot (20 beet) and taken to the sugar factory to be done as a result. Laboratory analyzes included measuring the sugar content in the root (\%).

\section{Agroecoligical conditions}

Beside soil conditions, meteorological conditions have also large impact on plant growing (Popović, 2010). Rosso and Candolo (2001) conclude that meteorological conditions at vegetation period have very important impact on genetic potential of variety fertility.

Mean monthly air temperatures during the investigation, as well as multiyear average (2003 - 2012) in the vegetation period of sugar beet, are shown in Table 1.

Table 1. Temperature $\left({ }^{\circ} \mathrm{C}\right)$ for the growing period of sugar beet, 2013-2014, Zrenjanin, Zlatica locality, Serbia

\begin{tabular}{|c|c|c|c|c|c|c|c|c|c|}
\hline Year/Month & III & IV & V & VI & VII & VIII & IX & X & Average \\
\hline 2013 & 7.6 & 13.3 & 17.2 & 23.3 & 25.5 & 24.4 & 20.3 & 14.6 & 18.3 \\
\hline 2014 & 9.8 & 13.2 & 16.5 & 19.9 & 22.3 & 21.4 & 17.0 & 13.5 & 16.7 \\
\hline $\begin{array}{c}\text { Average } \\
\text { 2003-2012 }\end{array}$ & 7.7 & 13.7 & 18.9 & 22.4 & 23.6 & 23.9 & 18.4 & 12.7 & 17.7 \\
\hline
\end{tabular}


In both study years, mean monthly air temperature increases from April to July, and then decreases. The average air temperature for the growing period of sugar beet were lower in the second year of study (2014) and was $16.7^{\circ} \mathrm{C}$. In 2013, the average air temperature was $18.3^{\circ} \mathrm{C}$, as compared with several years average greater value to $0.6^{0} \mathrm{C}$. Data for sum of rainfall per month for vegetation period of sugar beet during the investigation, as well as multi-year average (2003 - 2013) are shown in Table 2.

Table 2. Rainfall (mm) for the growing period of sugar beet, 2013-2014, Zrenjanin, Zlatica locality, Serbia

\begin{tabular}{|c|c|c|c|c|c|c|c|c|c|}
\hline Year/Month & III & IV & V & VI & VII & VIII & IX & X & Summ \\
\hline 2013 & 83.0 & 27.9 & 76.9 & 72.2 & 17.9 & 40.3 & 58.1 & 20.1 & 396.4 \\
\hline 2014 & 38.0 & 58.5 & 211.0 & 48.0 & 178.5 & 70.0 & 110.6 & 48.9 & 763.5 \\
\hline $\begin{array}{c}\text { Average } \\
\text { 2003-2012 }\end{array}$ & 44.5 & 54.5 & 95.4 & 76.4 & 60.5 & 55.3 & 49.3 & 52.7 & 488.6 \\
\hline
\end{tabular}

Years in which they performed these tests with each other widely, both in terms of the total amount of rainfall during the vegetation period of sugar beet, and in terms of their schedule by months. Significantly higher amount of rainfall was registered in 2014 and amounted to $763.5 \mathrm{~mm}$. At the contrary, in 2013 volume of rainfall for the growing season of sugar beet on the Zlatica locality was $396.4 \mathrm{~mm}$, which is compared with a long period less the sum of $92.2 \mathrm{~mm}$

\section{Root yield}

\section{RESULTS AND DISCUSSION}

Results of new studies show that, on average for the examined factors, root yield was $75.87 \mathrm{t} \mathrm{ha}^{-1}$, Tab.3.

Tab.3. The influence of cultivar and harvest date on sugar beet yield (t/ha)

\begin{tabular}{|c|l|c|c|c|c|}
\hline \multirow{3}{*}{ Year } & Cultivar (A) & \multicolumn{3}{|c|}{ Harvest date (B) } & Index \\
\cline { 2 - 5 } & & I & II & Average & $(\%)$ \\
\hline \multirow{7}{*}{2013} & Alfonsa & 69.05 & 82.23 & 75.64 & 100 \\
\cline { 2 - 5 } & Marianka & 68.11 & 75.76 & 71.94 & 95.01 \\
\cline { 2 - 5 } & Terranova & 69.80 & 77.92 & 73.86 & 97.60 \\
\cline { 2 - 5 } & Odessa & 64.09 & 75.06 & 69.58 & 91.90 \\
\cline { 2 - 5 } & $\begin{array}{l}\text { Jasmina } \\
\text { EPD }\end{array}$ & 59.17 & 73.53 & 66.35 & 87.70 \\
\cline { 2 - 5 } & Bruna EPD & 61.64 & 69.05 & 65.35 & 86.40 \\
\cline { 2 - 5 } & $\begin{array}{l}\text { Marinela } \\
\text { EPD }\end{array}$ & 63.31 & 74.97 & 69.14 & 91.40 \\
\cline { 2 - 5 } & Serenada & 66.72 & 73.58 & 70.15 & 92.70 \\
\cline { 2 - 5 } & EPD & & & & \\
\cline { 2 - 5 } & Average & 65.24 & 75.26 & 70.25 & 100 \\
\cline { 2 - 5 } & Index (\%) & 100 & 115.4 & $/$ & \\
\hline
\end{tabular}




\begin{tabular}{|c|l|c|c|c|c|}
\hline \multirow{5}{*}{2014} & Alfonsa & 83.9 & 88.28 & 86.09 & 100 \\
\cline { 2 - 6 } & Marianka & 72.31 & 79.30 & 75.81 & 88.10 \\
\cline { 2 - 6 } & Terranova & 81.53 & 94.07 & 87.80 & 101.90 \\
\cline { 2 - 6 } & Odessa & 81.43 & 88.51 & 84.97 & 98.70 \\
\cline { 2 - 6 } & $\begin{array}{l}\text { Jasmina } \\
\text { EPD }\end{array}$ & 66.87 & 73.76 & 70.32 & 81.70 \\
\cline { 2 - 6 } & Bruna EPD & 69.84 & 80.24 & 75.04 & 87.20 \\
\cline { 2 - 6 } & $\begin{array}{l}\text { Marinela } \\
\text { EPD }\end{array}$ & 80.54 & 87.88 & 84.21 & 97.80 \\
\cline { 2 - 6 } & $\begin{array}{l}\text { Serenada } \\
\text { EPD }\end{array}$ & 83.60 & 91.73 & 87.67 & 101.80 \\
\cline { 2 - 6 } & Average & 77.50 & 85.47 & 81.49 & $/$ \\
\cline { 2 - 6 } & Index (\%) & 100 & 110.30 & $/$ & 116 \\
\hline \multirow{5}{*}{ Alfonsa } & 76.48 & 85.26 & 80.87 & 100 \\
\cline { 2 - 6 } & Marianka & 70.21 & 77.53 & 73.88 & 91.40 \\
\cline { 2 - 6 } & Terranova & 75.67 & 85.99 & 80.83 & 99.90 \\
\cline { 2 - 6 } & Odessa & 72.76 & 81.79 & 77.28 & 95.60 \\
\cline { 2 - 6 } & $\begin{array}{l}\text { Jasmina } \\
\text { EPD }\end{array}$ & 63.02 & 73.65 & 68.34 & 84.5 \\
\hline & Bruna EPD & 65.74 & 74.65 & 70.20 & 86.8 \\
\cline { 2 - 6 } & $\begin{array}{l}\text { Marinella } \\
\text { EPD }\end{array}$ & 71.93 & 81.43 & 76.68 & 94.8 \\
\cline { 2 - 6 } & $\begin{array}{l}\text { Serenada } \\
\text { EPD }\end{array}$ & 75.16 & 82.66 & 78.91 & 97.6 \\
\hline & Average & 71.37 & 80.37 & 75.87 & $/$ \\
\cline { 2 - 6 } & Index(\%) & 100 & 112,6 & $/$ & $/$ \\
\hline
\end{tabular}

Tab.3.1. ANOVA of the influence of cultivar and harvest date on sugar beet yield

\begin{tabular}{|c|c|c|c|c|c|c|c|c|}
\hline \multirow{2}{*}{ LSD } & \multicolumn{4}{|c|}{2013} & \multicolumn{4}{c|}{2014} \\
\cline { 2 - 9 } & $\mathrm{A}$ & $\mathrm{B}$ & $\mathrm{B} \times \mathrm{A}$ & $\mathrm{A} \times \mathrm{B}$ & $\mathrm{A}$ & $\mathrm{B}$ & $\mathrm{B} \times \mathrm{A}$ & $\mathrm{A} \times \mathrm{B}$ \\
\hline 0.05 & 3.13 & 1.54 & 4.36 & 4.37 & 5.88 & 2.15 & 6.09 & 7.24 \\
\hline 0.01 & 4.23 & 2.03 & 5.80 & 5.75 & 7.95 & 2.84 & 8.02 & 9.64 \\
\hline
\end{tabular}

The year 2014 has been measured higher root yield of 16.0\% compared to 2013. In the first year of investigation (2013), the highest root yield (75.64 tha ${ }^{-1}$ ) was measured in a variety of Alfonso. In contrast, in 2014, the highest root yield was recorded in $\mathrm{cv}$ Terranova $\left(87.80 \mathrm{t} \mathrm{ha}^{-1}\right)$, then the variety Serenade EPD $\left(87.67 \mathrm{t} \mathrm{ha}^{-1}\right)$, (Table 3). The lowest root yield, the two-year average (68.34 $\left.\mathrm{t} \mathrm{ha}^{-1}\right)$ was found in the variety Jasmina EPD. On average for the variety and, in the second lifting achieved greater root yield of $9.0 \mathrm{t}$ ha- 1 or $12.6 \%$ compared to the first term extraction (Table 3). 


\section{The sugar content in root}

The results of our research show that, on average, for the investigated factors, the sugar content was 15.11\% (Table 4). In 2013 measured the higher sugar content by $3.79 \%$ compared to 2014 and amounted to $17.01 \%$. In both years the highest sugar content (average 15.52\%) was measured in a variety Jasmina EPD.

Tab. 4. The influence of cultivar and harvest date on sugar content in root (\%)

\begin{tabular}{|c|c|c|c|c|c|}
\hline \multirow[t]{2}{*}{ Year } & \multirow[t]{2}{*}{ Cultivar (A) } & \multicolumn{3}{|c|}{ Harvest date (B) } & \multirow{2}{*}{$\begin{array}{c}\text { Index } \\
(\%)\end{array}$} \\
\hline & & $\mathrm{I}$ & II & Average & \\
\hline \multirow{10}{*}{2013} & Alfonsa & 17.08 & 16.50 & 16.79 & 100 \\
\hline & Marianka & 17.49 & 16.56 & 17.03 & 101.4 \\
\hline & Terranova & 17.14 & 16.58 & 16.86 & 100.4 \\
\hline & Odessa & 17.15 & 17.10 & 17.13 & 102.0 \\
\hline & \begin{tabular}{|l|} 
Jasmina EPD \\
\end{tabular} & 17.34 & 17.00 & 17.17 & 102.3 \\
\hline & Bruna EPD & 17.14 & 17.04 & 17.09 & 101.8 \\
\hline & \begin{tabular}{|l} 
Marinela EPD \\
\end{tabular} & 17.30 & 16.56 & 16.93 & 100.8 \\
\hline & \begin{tabular}{|l|} 
Serenada \\
EPD
\end{tabular} & 17.26 & 16.83 & 17.05 & 101.6 \\
\hline & Average & 17.24 & 16.77 & 17.04 & 1 \\
\hline & Index (\%) & 100.0 & 97.3 & 1 & 100 \\
\hline \multirow{10}{*}{2014} & Alfonsa & 11.98 & 11.31 & 11.65 & 100 \\
\hline & Marianka & 13.54 & 13.01 & 13.28 & 114.0 \\
\hline & Terranova & 13.31 & 13.01 & 13.16 & 113.0 \\
\hline & Odessa & 13.56 & 13.44 & 13.50 & 115.9 \\
\hline & Jasmina EPD & 14.26 & 13.47 & 13.87 & 119.1 \\
\hline & Bruna EPD & 13.48 & 13.31 & 13.40 & 115.0 \\
\hline & \begin{tabular}{|l|} 
Marinella \\
EPD
\end{tabular} & 13.44 & 13.30 & 13.37 & 115.8 \\
\hline & $\begin{array}{l}\text { Serenada } \\
\text { EPD }\end{array}$ & 13.37 & 13.61 & 13.49 & 115.8 \\
\hline & Average & 13.37 & 13.06 & 13.22 & 1 \\
\hline & Index (\%) & 100 & 97.7 & 1 & 77.7 \\
\hline \multirow{10}{*}{ Average } & Alfonsa & 14.53 & 13.91 & 14.22 & 100 \\
\hline & Marianka & 15.52 & 14.79 & 15.16 & 106.6 \\
\hline & Terranova & 15.23 & 14.80 & 15.02 & 105.6 \\
\hline & Odessa & 15.36 & 15.27 & 15.32 & 107.7 \\
\hline & Jasmina EPD & 15.80 & 15.24 & 15.52 & 109.1 \\
\hline & Bruna EPD & 15.31 & 15.18 & 15.25 & 107.2 \\
\hline & \begin{tabular}{|l|} 
Marinella \\
EPD \\
\end{tabular} & 15.37 & 14.93 & 15.15 & 106.5 \\
\hline & \begin{tabular}{|l|} 
Serenada \\
EPD
\end{tabular} & 15.32 & 15.22 & 15.27 & 107.4 \\
\hline & Average & 15.30 & 14.92 & 15.11 & 1 \\
\hline & Index (\%) & 100 & 97.5 & I & 1 \\
\hline
\end{tabular}


In contrast, the average for the year and harvesting time, the minimum sugar content (14.22\%) was found in the variety of Alfonso. On average for the variety and the year, in the first lifting achieved higher sugar content by $2.5 \%$ in comparison with the other term extraction.

Table 4.1. ANOVA of the influence of cultivar and harvest date on sugar content in root

\begin{tabular}{|c|c|c|c|c|c|c|c|c|}
\hline \multirow{2}{*}{ LSD } & \multicolumn{4}{|c|}{2013} & \multicolumn{4}{|c|}{2014} \\
\cline { 2 - 9 } & $\mathrm{A}$ & $\mathrm{B}$ & $\mathrm{B} \times \mathrm{A}$ & $\mathrm{A} \times \mathrm{B}$ & $\mathrm{A}$ & $\mathrm{B}$ & $\mathrm{B} \times \mathrm{A}$ & $\mathrm{A} \times \mathrm{B}$ \\
\hline 0.05 & 0.42 & 0.21 & 0.59 & 0.58 & 0.52 & 0.19 & 0.55 & 0.64 \\
\hline 0.01 & 0.56 & 0.27 & 0.78 & 0.77 & 0.70 & 0.26 & 0.72 & 0.86 \\
\hline
\end{tabular}

The proper selection of varieties for a particular product area contributes to greater and more stable production of cultivated plants. In order to cost-effective production and processing of sugar beet cultivation it is reasonable to saw varieties of all three main directions of selection: $\mathrm{Z}$ (high content of sugar), $\mathrm{N}$ (normal) and E (high yield) (Stanaćev, 1979, Bojovic et al., 2014). The proposed manufacturing process for beet varieties share in the total sawed surface should be: $20 \% \mathrm{Z}, 50 \%$ of $\mathrm{N}$ and $30 \%$ E type, but each manufacturer must be free to determine the basis of its own organizational and economic opportunities (Bojović et al, 2014).

Drought is a major limiting factor in sugar beet yields in many areas. Varieties with increased tolerance to drought can be partially mitigated the harmful consequences of drought. These varieties have certain genotypic and phenotypic characteristics. Genotypic characteristics is the root system with a larger absorption surface, more developed palisade tissue, thicker cuticle, fewer stomata, higher content of bound water, more osmotic active substances and the like (Bojović et al, 2014).

Proper protection of crops is very important for a good sugar beet yield. Proper protection makes repeated use of chemicals to seeds and young plants. In the area of South Banat (where experiments are performed) recorded the presence of 160 weed species (Nestorović, 2005). Suppression of herbicides is justified only if they achieve high yield (Ivanovic et al. 1999). The most common diseases on sugar beet causing pathogens Cercospora and Rhizomania that must be combated with chemical preparations. In the absence of chemical treatment of the foliage can be completely collapse, leading to a complete loss of yield. Attack of the parasites can reduce 1-2\% of sugar content in the roots (Stojšin et al. 2008; Bojovic et al, 2014).

The quality of sugar beet is complex characteristic, caused by genetic differences between varieties and diverse environmental conditions in the area of cultivation (Rosso and Candolo, 2001). In all cultivated plants there is interaction between genotype (variety) and external environment. Sugar beet, in addition to its adaptability to climatic conditions, reacts quickly to changes in meteorological 
factors which greatly affect root yield and sugar content. For a good yield it requires a mean temperature of 15.3 to $16.4^{\circ} \mathrm{C}$ (Bojovic, 2014).

\section{CONCLUSION}

Based on the results of two-year examination of the effect of the cultivar and the harvest date on the yield and quality of sugar beet conducted in agroecological conditions of Central Banat, it can be concluded:

$\checkmark$ A year in which they carried out research on the effect of the lifting of the variety and the yield and quality of sugar beet, it differed in terms of meteorological conditions, both in the amount and distribution of rainfall, and in thermal conditions.

$\checkmark$ The yield of sugar beet depended to a greater extent than genotype of the lifting. The lowest average root yield (68.34 $\mathrm{t}$ ha-1) was achieved in varieties Jasmina EPD and the highest (80.87 tha-1) in a variety of Alfonso with a difference of $12.53 \mathrm{t}$ ha- 1 or $15.5 \%$. In the second lifting date there has been greater root yield by $9.0 \mathrm{t}$ ha- 1 or $12.6 \%$ compared to the first period.

The sugar content in sugar beet root is the most dependent on the weather conditions. In 2013 sušnijoj sugar content was higher by 3.88\% compared to the wetter and colder in 2014. In both years the greatest sugar content (average $15.52 \%$ ) was found in the variety Jasmina EPD, and the lowest in cultivar Alfonso (average 14.22\%). The first lifting recorded a higher sugar content $(0.38 \%)$ compared to the second term.

\section{ACKNOWLEDGEMENTS}

Research was supported by the Ministry of Education and Science of the Republic of Serbia (Projects: TR 31078 and TR 31022).

\section{REFERENCES}

Bojović, R., Glamočlija, Đ., Popović, Vera, Popović, B., Filipović ,V., Kuzevski, J., 2014. Sugar beet yield parameters on carbonate chernozem soil type. Agriculture and Forestry, Vol. 60. Issue 3: 41-53, 2014, Podgorica.

Filipović, V., Glamočlija,Đ., Jaćimović,G. (2009): Uticaj gustine useva i rokova vađenja na prinos i kvalitet različitih sorti šećerne repe. Plant Breeding and Seed Production, Vol. 15, broj 1, str: 45-53, Novi Sad.

Heidari,G., Sohrabi,Y. and Esmailpoor B. (2008): Influence of Harvesting Time on Yield and Yield Components of Sugar Beet. J.Agri.Soc.Sci.,4: 69-73.

Hussein, M. Al-Sayed, Usama, A. Abd El-Razek,Hazem, M. Sarhan, Hayam, S. Fateh (2012): Effect of Harvest Dates on Yield and Quality of Sugar Beet Varietes. Australian Journal of Basic and Applied Scinces., 6(9): 525-529.

Cacic N., Kovačev L. Mezei Snezana, Sklener P. (1997): The interaction genotype environment on production characteristics of sugar beet. Plant breeding and Seed. Novi Sad. Vol. 4 no. 1-2. p. 127-134. 
Knežević, M., Đurović, D., Mugoša, B., Strunjaš, M., Topalović, A. (2014): Relationships between parameters of soil and chard (Beta vulgaris L. var. Ciclo L.). Agriculture \& Forestry, Vol. 60, Issue 3, 275-283.

Kolarić, Lj., Gujaničić, Tihomir, Zivanovic, Lj., Ikanović, J., Popović, Vera (2015): The influence of cultivar and harvest date on Sugar beet yield and quality. Institute of PKB Agroekonomik, Padinska Skela, Belgrade, Serbia, p. 65-70.

Mahdi, Naghizadeh, Ali, Ali-Askari, Ali, Fadaie (2013): Study of Effects of Sowing and Harvest Date on Sugar Beet Quantity and Quality Traits. International Journal of Agronomy and Plant Production, Vol., 4(12), 3392-3395.

Nestorović, M. (2009): Korovska flora Pančevačkog rita. Savremena poljoprivreda, 58, 1-2, p.1-11.

Ninfale, P. \& Angelino D. (2013): Nutritional and functional potential of Beta vulgaris cicla and rubra. Fitoterapia 89: 188-199.

Ivanović, M., Marković S., Kuzevski J., Krstanović, S. (1999): Efikasnost herbicida pri primeni pre i posle nicanja šećerne repe. XIII savetovanje agronoma, veterinara i tehnologa, Aranđelovac, vol. 5, 1-5.

Jozefyova, L., Pulkrabek, J.,Urban, J. (2003): The Influence of Harvest Date and Crop Treatment on The Production of Two Different Sugar Beet Variety Types. Plant Soil Environ., 49, (11), 492-498.

Popović Vera (2010): Influence of agro-technical and agro-ecological practices on seed production of wheat, maize and soybean. Doctoral thesis. University of Belgrade, Faculty of Agriculture in Zemun, pp. 1-145, 45-65.

Rosso F., Candolo G. (2001): Evaluation of sugar beet main quality features through the analysis of the diffusion juices produced by y pilot plant. 64. IIRB Congress, Bruges, Belgium, 26-27 Jun 2001. v. 64 pp. 437-442.

Stanaćev, S. (1979): Sugar beet. Nolit, 1979.

Trifunović, S., Topalović, A., Knežević, M., Vajs, V. (2015): Free radicals and antioxidants: antioxidative and other properties of Swiss chard (Beta vulgaris L. subsp. Cicla). Agriculture and Forestry, Vol. 61, Issue 2: 73-92, 2015, Podgorica 